\title{
POWDERY MILDEW INFECTION ON SOME EGYPTIAN BREAD WHEAT CULTIVARS IN RELATION TO ENVIRONMENTAL CONDITIONS. \\ El-Shamy, M. M. ${ }^{*}$; M. E. A. Sallam ${ }^{*}$ and H. M. F. Awad ${ }^{* *}$ \\ * Wheat Dis. Res. Dept., Plant Pathology Research Institute, ARC. \\ Maize, Sugar Crops and Foliages Dis. Res. Dept.,Plant Pathology Research Institute, ARC, Giza ,Egypt.
}

\begin{abstract}
Wheat powdery mildew, caused by the biotrophic fungus Blumeria graminis (DC) E.O. Speer f. sp. tritici Em. Marchal, is one of the most severe foliar diseases attacking this crop, affecting wheat production under Mediterranean basin conditions through the last few years. Four bread wheat cultivars i.e.. Sakha-93, Gemmeiza-7, Gemmeiza-10, and Giza-160 as a check were evaluated to artificial inoculation of powdery mildew under field conditions. The tested wheat cultivars showed susceptible responses to powdery mildew with fluctuated values in 2010 and 2011 seasons. In 2010 season, the tested cultivars showed high levels of disease severity, ranged from 35 to $87 \%$ ( Gemmeiza-7 and Gemmeiza-10, respectively). While, in 2011 lower levels were recorded, from 6.00 up-to 15\% ( Sakha-93 and Gemmeiza-10, respectively). Area under disease progress curve (AUDPC) was correlated with disease severity during the two seasons. Also, the yield components, the thousand grain weight and the grain yield $/ \mathrm{m}^{2}$ were affected by disease severities with different values for each cultivar. High air temperature, wind speed and mild relative humidity played an important role in increasing powdery mildew infection level in 2010 season. Keywords: wheat, powdery mildew, Blumeria graminis f. sp. tritici.
\end{abstract}

\section{INTRODUCTION}

Powdery mildew, caused by the biotrophic fungus Blumeria graminis (DC) E.O. Speer f. sp. tritici Em. Marchal, is one of the most serious foliar diseases on bread Wheat (Triticum aestivum L.). In the last few years the importance of powdery mildew has increased on the commercially grown cultivars in Egypt due to the favorable environmental conditions. This disease is widely spreads during years with relatively mild weather during February and March. Mild temperatures, high relative humidity and dense stands of wheat favor epiphytotic spread of the disease. Volunteer wheat is important for survival of Blumeria graminis in areas where fall seeded wheat is grown (Mehta, 1993). Ascospores and conidia serve as primary inocula. Both spores are wind-blown with ascospores dispersed in midsummer and conidia disperse in spring. Both types of spores germinate when the relative humidity reaches $85-100 \%$. Free water on host tissue is not necessary for spore germination (Jarvis et al., 2002 ).

Infection during tillering, stem elongation and booting phases has great influence on yield, particularly when it occurs early (Bowen et a.l,1991 ). This disease results in reduction in grain size, test weight and ultimately lower yield. Greatest yield losses occur when the flag leaf becomes severely infected by heading. Imani et al.( 2002) stated that powdery mildew caused 
by Blumeria graminis $\mathrm{f}$. $\mathrm{sp}$. tritici is becoming a limiting factor in production of durum wheat (Triticum turgidum L. sp. durum) in the Mediterranean climate. Losses over $34 \%$ of the yield have been recorded (Pearce et al., 1996). Also, Costamilan (2005) stated that wheat powdery mildew, reduced grain yields by $10 \%$ to $62 \%$ in Brazil.

The disease could be controlled by genetic resistance of the host (Brown et al .,1997) but the pathogen has physiological specialization, which enables it to infect wheat cultivars that remained resistant for years. The use of systemic fungicides is reliable method to control the disease .This work was conducted to study the incidence and severity of powdery mildew on the yield of some bread wheat cultivars which commercially grown in Middle Delta Region.

\section{MATERIALS AND METHODS}

Field experiment was carried out at the farm of Gemmeiza Research Station which located at $30.97^{\circ} \mathrm{N} ; 31.122 \mathrm{E}$ and $4.00 \mathrm{~m}$ elevation, Gharbia governorate during 2010 and 2011 geowing seasons under artificial inoculation of powdery mildew. The experimental design was a randomized complete block with three replicates. Four bread wheat varieties were randomly allocated to plot of $4.2 \mathrm{~m}^{2}$ ( each consists of six rows with $3.5 \mathrm{~m}$ length and $20 \mathrm{~cm}$ apart ). Untreated plots were compared with plots kept nearly diseased-free with four foliar applications of two alternated fungicides : Flusilazole (Punch40\% EC) and Propiconazole (Tilt 25\%EC).The experiment was surrounded by plots of durum wheat varieties as highly susceptible source of powdery mildew( Nsarellah et al., 2000) . To carry out experiments, plots as well as the border were sown with adapted machine.

\section{Preparation of powdery mildew inocula:}

The inocula source were obtained from field grown durum wheat (Triticum turgidum L.var. durum ) plants infected naturally with Blumeria graminis DC f. sp. tritici at the Gemmeiza Research Station during 2010 and 2011 winter growing seasons. The inoculum was multiplied and propagated on healthy durum wheat plants 20-30 days old.This inoculation was carried out by shaking conidia from potted infected plants on potted healthy plants under greenhouse conditions (Fig. 1_A\&B ).

\section{Field inoculation Technique:}

The experimental plots were inoculated by dispersing conidia from the infected plants onto the leaves of the durum wheat border plants, which surrounded the experiment to promote homogeneous disease spread as well as by putting the inoculated plants inside each plot , one infected pot/plot ( Fig 2) . 


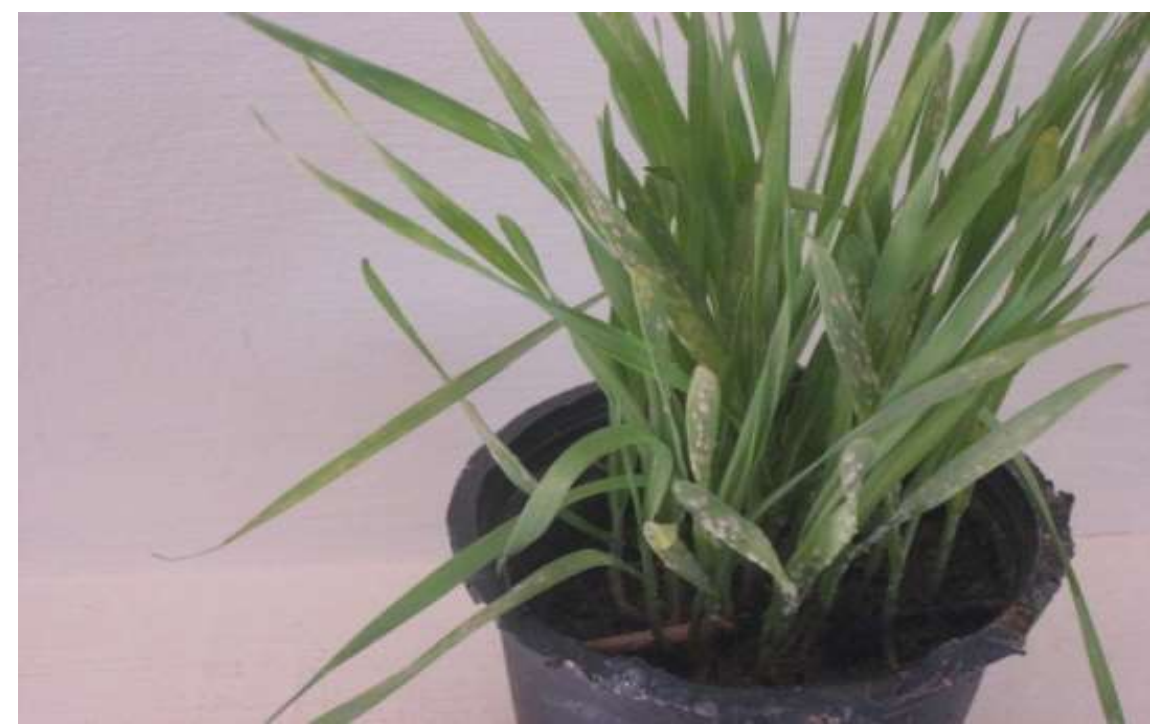

Fig.1: Conidia of powdery mildew multiplied on durum wheat plants under greenhouse conditions.

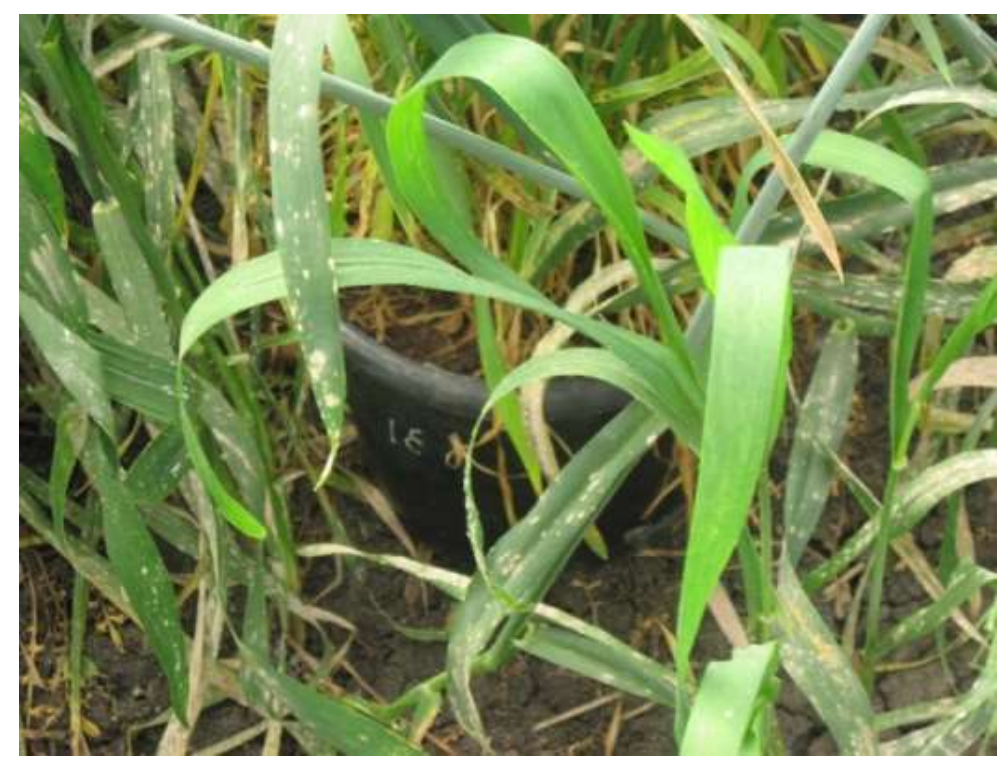

Fig. 2: Illustrate infected plants grown in pots used for inoculation inside the plot plants of the tested cultivar.

\section{Powdery mildew assessment:}

Mildew severity was scored by estimating the percentage of leaf area infected on the whole plot of each cultivar using the modified Cobb scale 0 to $100 \%$ (Peterson et al.1948). Disease severity assessments were taken five 
times at 10-day intervals during the season; the first scoring was done when the majority of lines were in the late booting stage (GS 45), and the last scores were taken around GS 75, when the most susceptible cultivar had reached maximum severity. These scores were used to calculate the area under disease progress curve (AUDPC) as described by Pandy( 1989).The AUDPC was estimated as follows: where :

AUDPC $=D\left[1 / 2\left(Y_{1}+Y_{k}\right)+\left(Y_{2}+Y_{3}+\cdots+Y_{k-1}\right)\right]$

D =Days between two consecutive recording (time intervals)

$\mathbf{Y}_{1}+\mathbf{Y}_{\mathbf{k}}=$ Sum of the first and last scores.

$Y_{2}+Y_{3}+\cdots+Y_{k-1}=$ Sum of all in between disease scores.

\section{Yield assessment :}

When plants reached the full maturity stage, 25 main tillers were selected at random along two diagonals from one corner to the opposite one of the plot. Spikes of all plots in the experiment were hand harvested, threshed and yield components were measured including the followings:

1-One thousand grain weight $(\mathrm{gm})$.

2-Total weight of grain $(\mathrm{kg})$ per $\mathrm{m}^{2}$

The reduction (\%) in each component was calculated according to the formula described by Evans et al., (1973) as follow;

Reduction (Loss) $\%=\left[\left(D_{2}-D_{1}\right) / D_{2}\right] \times 100$

Where, $D_{1}=$ Yield of infected plots

\section{Weather Data:}

$\mathrm{D}_{2}=$ Yield of protected plots .

Meteorological data were taken from the weather station at Gemmeiza Res. Station during months of powdery mildew appearance from January, to April. Temperature $\left({ }^{0} \mathrm{c}\right)$, wind speed $(\mathrm{m} \backslash \mathrm{sec})$, precipitate rain fall $(\mathrm{mm})$ and relative humidity (\%) were pooled to obtain a mean value for each month and year, at 2010 and 2011 growing seasons.

Statistical analysis:

All experiments were performed twice. Analyses of variance were out using MSTAT-C difference between treatments at $p<0.05$ (Gomez and Gomez.1984).

\section{RESULTS AND DISCUSSION}

None of the used bread wheat cultivars showed any resistant reaction against the pathogen in both experimental seasons.

First symptoms of powdery mildew in 2010 season were evident at the first half of February in plants with phenological growth stages between 20 and 30 according to the scale based of Zadoks et al., (1974). All the tested cultivars had variable levels of powdery mildew, since the mildew severities ranged from 2 on Sakha-93 to 20\% on Gemmeiza-10. During the 2010 season, severe infections of Blumeria graminis were recorded in the experimental cultivars, with percentages of leaves covered with mycelia often above $50 \%$ (Table 1 and Fig. 3). The mean percentage of powdery mildew on 
flag leaf $(F)$ and the first leaf below the flag leaf (F1) ranged from 35\% (Gemmeiza-7) to 87\% (Gemmeiza-10).The cultivars Sakha-93 and Giza-160 were intermediate since they scored $45 \%$ and $62 \%$ disease severity, respectively. While in 2011 season, It could be noticed that powdery mildew disease severity was very late and low compared with 2010 season since disease severity ranged from $6 \%$ on Sakha- $93,8 \%$ on Gemmeiza- $7,12 \%$ on Giza-160 and $15 \%$ on Gemmeiza-10. This fluctuation in powdery mildew infection might be related to the differences in weather conditions in the two seasons. Tomas and Solis (2000) found a large variation in disease severity of the cultivars in the field, ranging from 0 to $70 \%$, with different values in each repetition of the same place due to the spatial irregularity of the inoculum. Briceno-Flix et al.(2004) evaluated 5 Spain wheat cultivar against powdery mildew disease.

Table. 1: Powdery mildew severity\% (\% leaf area covered by mycelia) and area under disease progress curve(AUDPC) of four bread wheat cultivars under artificial inoculation in 2010 and 2011growing seasons.

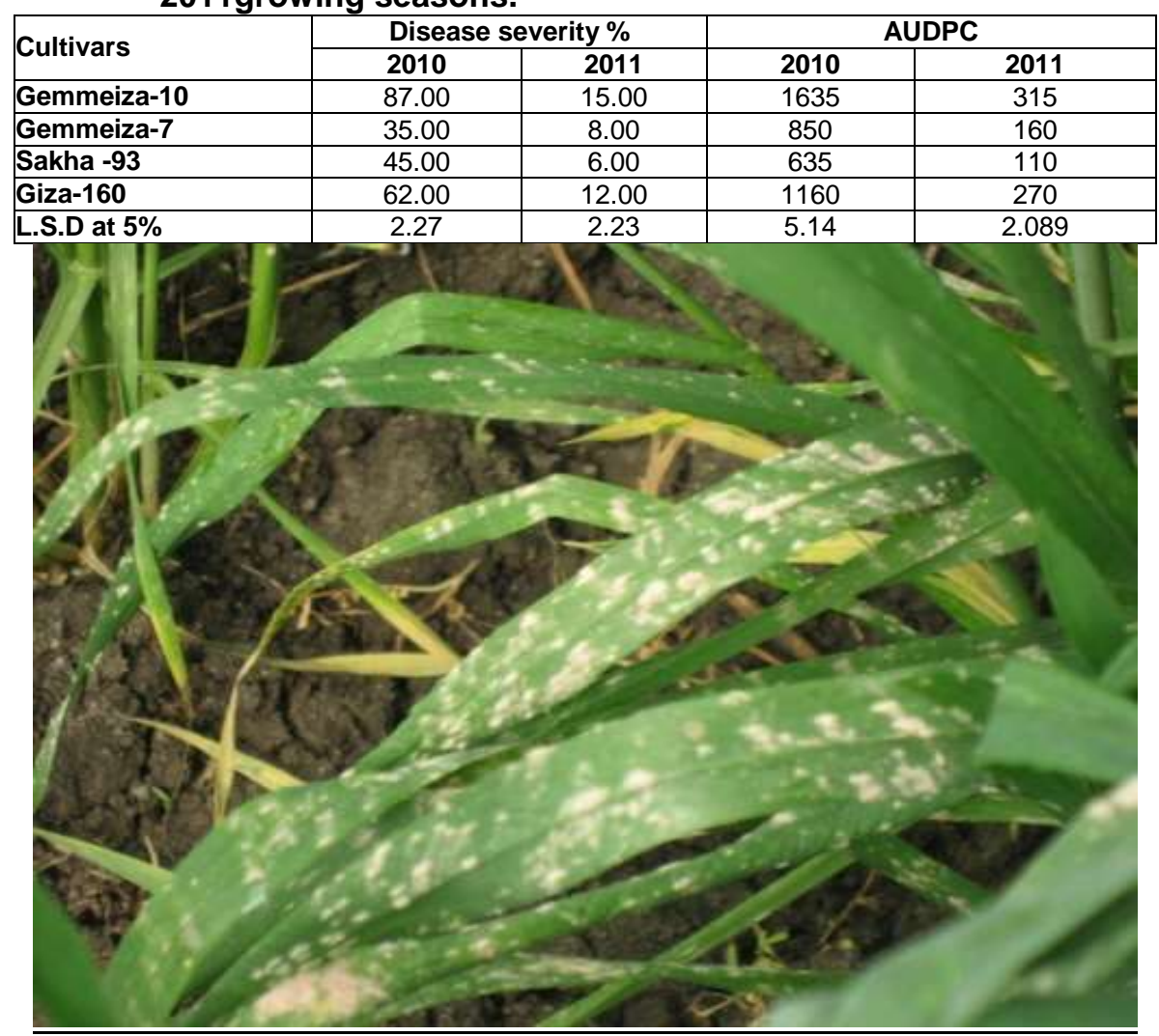

Fig.3 : illustrate severe infection of powdery mildew on experimental plants in 2010 growing season. 
They found that disease severity varied either between cultivars or between the three upper leaves. Disease severity at Zadoks growth stage 76 varied from 6.0 to $82.0 \%$ on flag leaf $(F), 12.0$ to $87.3 \%$ on flage-1 and 25.3 to $90.0 \%$ on flage-2 among the tested cultivars. The wheat cultivars Anza and Adalid were the most susceptible ones.

Area under disease progress curve (AUDPC) for the tested four cultivars was proportional with disease severity in 2010 or 2011 seasons. (Table 1 and fig. 4). The cultivar ranking in descending order was Gemmeiza$10(1635,315)$ followed by Giza-160 $(1160,270)$, Gemmeiza-7(850, 160), and Sakha-93 $(635,110)$ in the two seasons respectively based on AUDPC. Wang et al. (2005) showed that according to the AUDPC, maximum disease severity on the penultimate leaf, and the disease index are good indicators of the degree of adult plant resistance (APR) in the field. Carver and Ellis Griffiths (2008) found that the correlation between total yield of primary shoots and area under the mildew curve was high $(r=0.953)$.

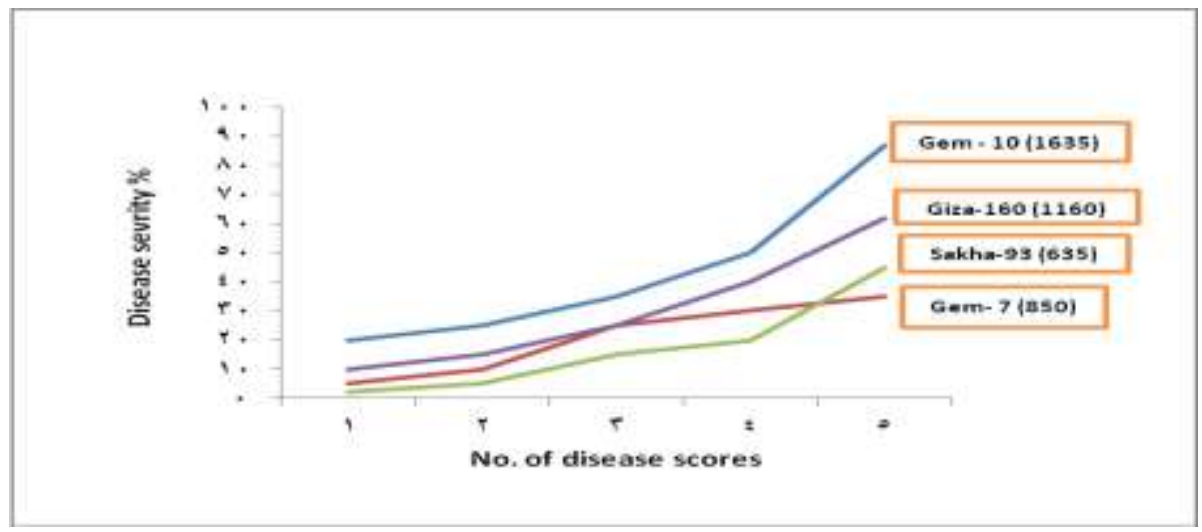

4 A (UDPC in 2010 growing season )

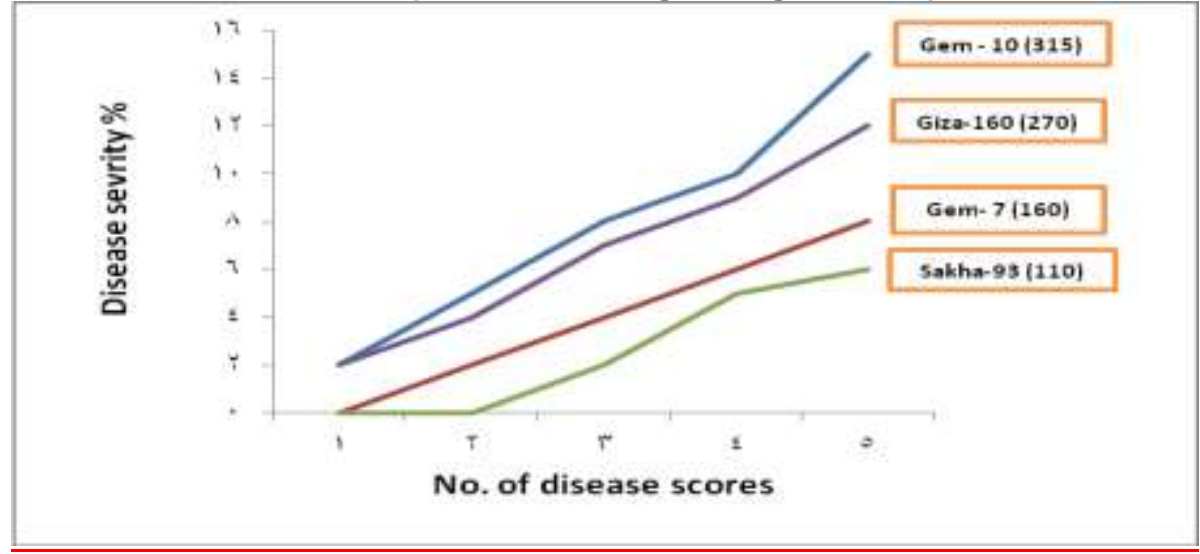

4 B (AUDPC in 2011 growing season)

Fig. 4 (A\&B): Powdery mildew disease severity\% and area under disease progress curve(AUDPC) on four bread wheat cultivars during 2010 and 2011 growing seasons. 


\section{Relationship between powdery mildew severity and environmental conditions:}

Highly significant differences were found between the response of the tested cultivars in powdery mildew infection. The tested_cultivars showed high powdery mildew disease severity in 2010 season than in 2011 season. This could be attributed to the differences in weather factors in the two seasons.

Data in Table 2 show meteorological factors prevalent from January to April ,2010 and 2011 .The values of air temp. av. $\left({ }^{\circ} \mathrm{c}\right)$, and wind speed (m) sec) in 2010 season were more than those in 2011 and this may be play an important role in dispersal of conidia of the pathogen between wheat plants than the other factors. Jarvis et al. (2002) stated that the optimal temperature for infection is around $15-20{ }^{\circ} \mathrm{C}$, but infection can take place between 5 $30^{\circ} \mathrm{C}$. High humidity $(85-100 \% \mathrm{RH})$ also favors spore germination but does not affect mycelium development. Powdery mildew spores are short lived, prefer high humidity but do not tolerate immersion in water. Te Beest et al., (2008) identified the key weather factors determining the occurrence and severity of powdery mildew epidemics on winter wheat. They used disease data from field experiments at 12 locations in the UK covering the period from 1994 to 2002 with matching data from weather stations within a $5 \mathrm{~km}$ range. Wind in December to February under the Egyptian conditions was the most influential factor for a damaging epidemic of powdery mildew. Disease severity was best identified by a model with temperature, humidity, and rain in April to June. Wiik and Ewaldz (2009) reported that weather factors in the preceding growing season influenced powdery mildew and brown rust. Mild winters and springs favored the biotrophs such as powdery mildew, brown rust and yellow rust.

Table. 2. Meteorological factors prevailed in impotent months to powdery mildew infection.

\begin{tabular}{|l|c|c|c|c|c|c|c|c|}
\hline \multirow{3}{*}{ Month } & \multicolumn{2}{|c|}{$\begin{array}{c}\text { Precipitate } \\
\text { Rain fall }(\mathbf{m m})\end{array}$} & \multicolumn{2}{c|}{$\begin{array}{c}\text { HC air temp. } \\
\text { av.. }\end{array}$} & \multicolumn{2}{c|}{$\begin{array}{c}\text { Relative } \\
\text { humidity }\end{array}$} & \multicolumn{2}{c|}{$\begin{array}{c}\text { Wind speed } \\
\text { (m/sec.) }\end{array}$} \\
\cline { 2 - 9 } & $\mathbf{2 0 1 0}$ & $\mathbf{2 0 1 1}$ & $\mathbf{2 0 1 0}$ & $\mathbf{2 0 1 1}$ & $\mathbf{2 0 1 0}$ & $\mathbf{2 0 1 1}$ & $\mathbf{2 0 1 0}$ & $\mathbf{2 0 1 1}$ \\
\hline January & 0.00 & 3.4 & 16.06 & 14.73 & 53.00 & 75.00 & 2.46 & 1.21 \\
\hline February & 0.00 & 3.2 & 16.96 & 13.86 & 45.00 & 73.00 & 3.43 & 1.12 \\
\hline Marsh & 0.03 & 10.2 & 18.26 & 14.04 & 46.66 & 78.00 & 3.06 & 1.06 \\
\hline April & 0.06 & 17.2 & 33.16 & 18.18 & 48.33 & 69.00 & 3.06 & 0.84 \\
\hline Average & 0.02 & 8.50 & 21.11 & 15.20 & 48.24 & 73.75 & 3.00 & 1.05 \\
\hline
\end{tabular}

\section{Yield reduction.}

Data in Tables $(3 \& 4)$ reveal that The loss in yield components was correlated with disease severity in 2010 and 2011 seasons. In 2010 season, significant differences were found either between protected or non-protected plots of cultivars and between cultivars in-relation to yield components, 1000 grain weight and Grain yield/ $\mathrm{m}^{2}$. The highest reductions \% in yield components were detected in Gemmeiza-10 wheat cv. i.e. 1000 grain weight $(16.72 \%)$ and grain yield $/ \mathrm{m}^{2}(17.73 \%)$, respectively ( Table 3 ). 
In 2011 season, low values of yield losses were detected compared with 2010 season. The loss in 1000 grain weight ranged from 0.17 to 0.47 , while grain yield $/ \mathrm{m}^{2}$ ranged from 0.27 to $1.28 \%$ (Table 4).Bowen et al. (1991) demonstrated that early season powdery mildew can affect yield by reducing the number of tillers that a plant produces or the number of kernels per head. Griffey et al,( 1993) stated that the susceptible cultivar Saluda had an average mean mildew severity( MMS) of $5.3 \%$. MMS and grain yield for Saluda were significantly negatively correlated in both years, and yield loss averaged $13.4 \%$ in untreated plots relative to full-season control plots .Patrick E. Lipps. (1996) stated that losses up to 45 percent have been documented in Ohio on susceptible varieties when plants were infected in April and weather conditions were favorable for spread of the fungus throughout the growing season. Tomas and Solis (2000) found that the yield and powdery mildew severity results of each plot collected in Jerez de la Frontera showed a high uniformity in three repetitions data and a negative correlation between the average yield for each cultivar and its powdery mildew severity $(r=-$ 0.580 ).

Table (3): Effect of Powdery mildew (Blumeria graminis) infection on percentage yield reduction of four bread Wheat cultivars in 2010 growing season.

\begin{tabular}{|c|c|c|c|c|c|c|}
\hline Cultivar & Treatment & \begin{tabular}{|c|} 
Disease \\
severity \%
\end{tabular} & $\begin{array}{c}1000 \text { grain } \\
\text { weight (gm.) }\end{array}$ & \begin{tabular}{|c|} 
Loss \\
$\%$
\end{tabular} & \begin{tabular}{|c} 
Grain yield/ \\
$\mathbf{m}^{2}(\mathrm{Kg})$.
\end{tabular} & $\begin{array}{c}\text { Loss } \\
\%\end{array}$ \\
\hline \multirow[t]{2}{*}{ Gemmeiza-7 } & Protected & & 37.733 & & 1.780 & \\
\hline & Infected & 35.00 & 34.113 & 9.59 & 1.600 & 10.11 \\
\hline \multirow[t]{2}{*}{ Gemmeiza-10 } & Protected & & 34.073 & & 1.613 & \\
\hline & Infected & 87.00 & 28.373 & 16.72 & 1.327 & 17.73 \\
\hline \multirow[t]{2}{*}{ Sakha-93 } & Protected & & 37.770 & & 1.537 & \\
\hline & Infected & 45.00 & 34.092 & 9.73 & 1.360 & 11.51 \\
\hline \multirow[t]{2}{*}{ Giza-160 } & Protected & & 31.203 & & 1.780 & \\
\hline & Infected & 62.00 & 26.893 & 13.81 & 1.490 & 16.29 \\
\hline L.S.D. at $0.05 \%$ & & & 2.238 & & 0.071 & \\
\hline
\end{tabular}

Table (4): Effect of Powdery mildew (Blumeria graminis )infection on percentage yield reduction of four bread Wheat cultivars in 2011 growing season.

\begin{tabular}{|c|c|c|c|c|c|c|}
\hline Cultivar & Treatment & \begin{tabular}{|c|} 
Disease \\
severity \% \\
\end{tabular} & \begin{tabular}{|c|}
1000 grain \\
weight (gm.)
\end{tabular} & $\begin{array}{c}\text { Loss } \\
\%\end{array}$ & $\begin{array}{c}\text { Grain yield } / \mathbf{m}^{2} \\
(\mathrm{Kg})\end{array}$ & \begin{tabular}{|c} 
Loss \\
$\%$
\end{tabular} \\
\hline \multirow[t]{2}{*}{ Gemmeiza-7 } & Protected & & 40.660 & & 1.845 & \\
\hline & Infected & 8.00 & 40.590 & 0.17 & 1.840 & 0.27 \\
\hline \multirow[t]{2}{*}{ Gemmeiza-10 } & Protected & & 33.923 & & 1.864 & \\
\hline & Infected & 15.00 & 33.670 & 0.74 & 1.840 & 1.28 \\
\hline \multirow[t]{2}{*}{ Sakha-93 } & Protected & & 38.263 & & 1.760 & \\
\hline & Infected & 8.00 & 38.197 & 0.17 & 1.750 & 0.56 \\
\hline \multirow[t]{2}{*}{ Giza-160 } & Protected & & 32.477 & & 1.650 & \\
\hline & Infected & 12.00 & 32.343 & 0.41 & 1.640 & 0.60 \\
\hline L.S.D. at $\mathbf{0 . 0 5 \%}$ & & & 0.081 & & 0.012 & \\
\hline
\end{tabular}




\section{REFERENCES}

Bowen K.L., Everts K.L. and Leath S. 1991.Reduction in yield on winter wheat in North Carolina due to powdery mildew and leaf rust. Phytopathology_81, 5:503-511.

Briceno-Flix, G. Huerta-Espino, T., Tomas I. Ruis, L. Betese, J.A., and Martin Sanchez, J.A. 2004. Yield losses caused by powdery mildew on bread wheat cultivars under irrigated Mediterranean conditions in Spain. Options Mediterraneenes, Series A, No.81: $183-185$.

Brown J.K.M., Foster E.M. and O'HARA R.B., 1997. Adaptation of powdery mildew populations to cereal varities in relation to durable and non-durable resistance. In: The gene-for-gene relationship in plant-parasite interactions. (I.R. Crute, E.B. Holub, J.J. Burdon, eds), Ed. Cab International, UK, pp. 119-138.

Carver, T. L. W. and Ellis Griffiths. 2008. Relationship between powdery mildew infection, green leaf area and grain yield of barley. Annals of Applied Biology Volume 99 Issue 3, Pages 255 - 266.

Costamilan M.Leila. 2005. Variability of the wheat powdery mildew pathogen Blumeria graminis f. sp. tritici in the 2003 crop season. Fitopatologia Brasileira 30:420-422. 2005.

Evans, E., Marshal J. and Richard M.M..1973. Development of chloroquinox recommendations for mildew control of spring barley. Proc. $7^{\text {th }} \mathrm{Br}$., Insectic. Fungic. Conf., 1: $39-46$.

Griffey, C. A., Das, M. K. and Stromberg, E. L. 1993.Effectiveness of adult-plant resistance in reducing grain yield loss to powdery mildew in winter wheat. American Phytopathological Society, vol. 77, n6, pp. 618-622 (30 ref.) St.

Gomez,K.A., Gomez,.A., 1984. Statistical Procedures for Agricultural Research .A v. Lviley . Interscience Publication. New York ,pp.678 .

Imani , Y., Ouassou, A.and Griffey, C.A., 2002. Virulence of Blumeria graminis $\mathrm{f}$. sp. tritici populations in Morocco. Plant Dis. 86, 383-388.

Jarvis, W.R., Gubler, W.G. and Grove, G.G.. 2002. Epidemiology of powdery mildew in agricultural patho-systems. p. 169-199. In Bélanger, R.R., W.R. Bushnell, A.J. Dik and T.L.W. Carver (ed). The powdery mildews: A comprehensive treatise. The American Phytopathological Society, St. Paul, MN.

Mehta, Y.R.and Oidio del trigo. 1993 Mango Integratdo de Enfemedades del Trigo. Santa Cruz de la Sierra. In Mehta, Y.R.(Ed) CIAT. Pp. 230 - 237

Nsarellah N., Nachit M. and Lhaloui S. 2000. Breeding durum wheat for biotic stresses in the Mediterranean region. Proc. Durum wheat improvement in the Mediterranean region: New challenges, Zaragoza. (C. Royo, M.M. Nachit, N. Di Fonzo, J.L. Araus, eds) CHEAM, IRTA, CIMMYT e ICARDA, pp. 341-347.

Pandy, H.N., Menon T.C. and Rao M.V.1989. A simple formula for calculating area under disease progress curve. Rachis, 8(2): $38-39$.

Patrick E. Lipps. 1996. Powdery Mildew of Wheat "' Wheat Disease Control in Ohio. Plant Pathology, AC-10-96 ,OSU Extension bulletin 785. 
Pearce W.L., Van Sanford D.A. and Hershman D.E., 1996. Partial resistance to powdery mildew in soft red winter wheat. Plant Dis. 80, 1359-1362.

Peterson R.F., Campbell A.B. and Hannah A.E., 1948. A diagnostic scale for estimating rust intensity of leaves and stem of cereals. Can J Res Sect C26, 496-500.

Te Beest, D.E., Paveley, N.D., Shaw, M.W. and Van den Bosch, F. 2008. Diseaseweather relationship for powdery mildew and yellow rust on winter wheat. The American Phytopathology Society, Vol.98(5) : 609 - 617.

Tomas A. and Solis I. 2000. Effects of powdery mildew (Blumeria graminis) severity on durum wheat cultivars. Ciheam-Options Mediterraneennes. 417419.

Wang Z. L., Li L. H.; He Z. H., Duan Y., Zhou Y. L., Chen X. M., Lillemo M. and Singh R. P. and Wang H. and Xia X. C. 2005. Seedling and Adult Plant Resistance to Powdery Mildew in Chinese Bread Wheat Cultivars and Lines. The American Phytopathological Society May 2005, Volume 89, Number 5 Pages 457-463.

Wiik, L. and Ewaldz, T. 2009 .Impact of temperature and precipitation on yield and plant diseases of winter wheat in southern Sweden 1983-2007 . Crop Protection, Vol. 28, Issue 11, : 952-962.

Zadoks, J.C. Chang, T.T. and Konzak, C.F. 1974. A domical code for the growth of cereals. $14: 415-421$.

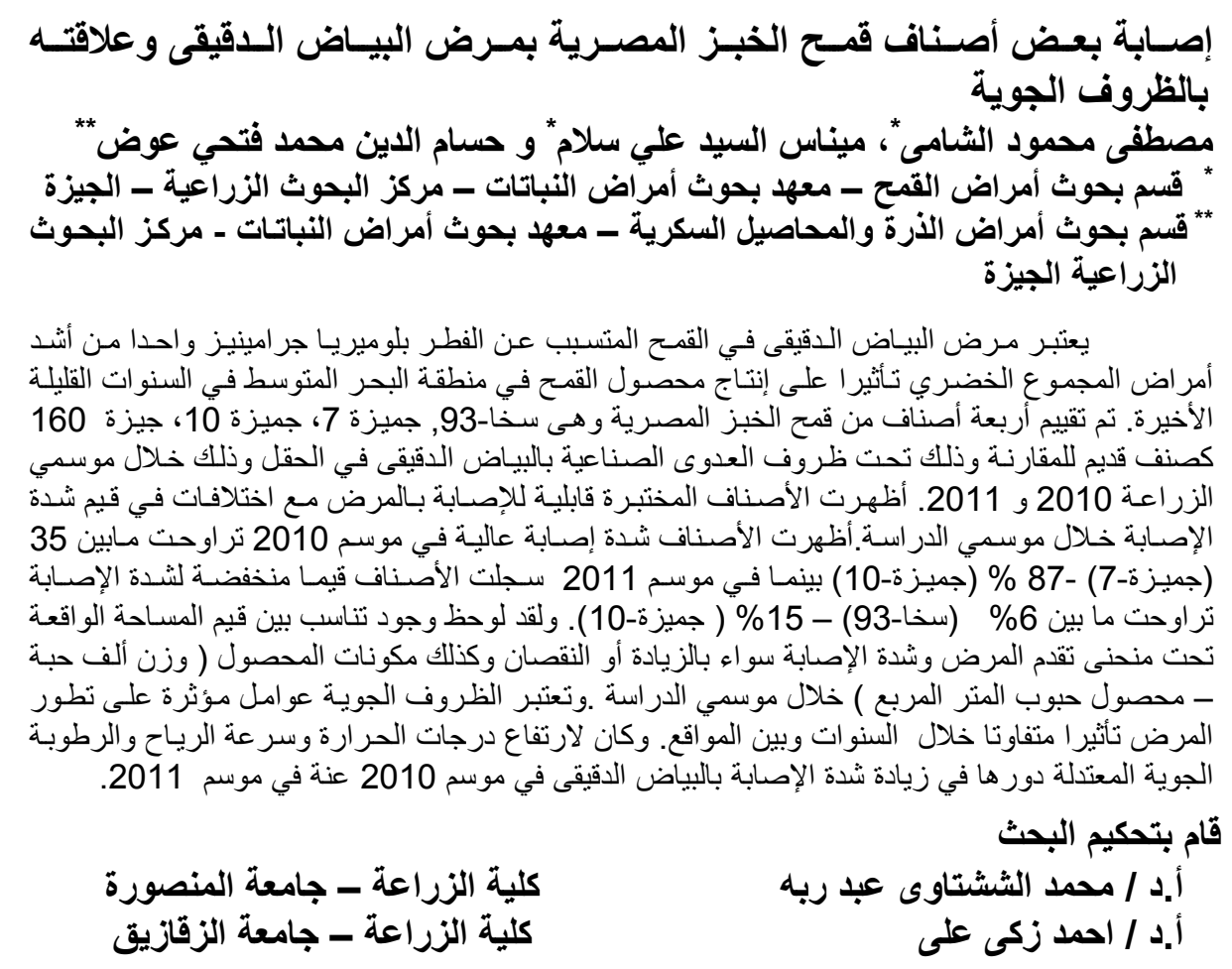


J. Plant Prot. and Path., Mansoura Univ., Vol. 3 (4), April, 2012 